\title{
The Position of Auxiliary Organ in Government System of West Java Provincial Government
}

\author{
Abdillah $^{\left.1^{*}\right)}$, Nandang Alamsyah Deliarnoor ${ }^{1}$, Neneng Yani Yuningsih ${ }^{1}$, Fatmawati $^{2}$ \\ ${ }_{1}^{1}$ Postgraduate Program of Government Studies, Faculty of Social and Political Sciences, \\ Universitas Padjadjaran, Jl. Bukit Dago Utara No.25 Bandung, 40135, West Java, Indonesia. \\ 2Department of Public Administration, Faculty of Social and Humanities, Universitas \\ Muhammadiyah Bandung, Jl. Soekarno - Hatta No. 752, Cipadung Kidul, Panyileukan, \\ Bandung, 40614, West Java, Indonesia.
}

Received: 2020-06-01; Accepted: 2020-09-27; Published: 2020-10-27

\begin{abstract}
This Article aims to explain how the West Java Quick Response position in the West Java regional government system 2018-2020 as an auxiliary institution outside the main government institutions is a new problem in the West Java regional government system. This type of research is qualitative with descriptive type. Data collection techniques are observation, interview, and documentation. The number of informants are 11 people who are determined proportionally. The results showed that the position of West Java Quick Response in the local government system in West Java 2018-2020 by looking at the two principles of independent institution criteria, namely First, the Policy Principle, and second, the Tenure or not-Political Party Principle. It can be concluded that West Java's Quick Response position in the regional government system of West Java 2018-2020 is not only a supporting institution, which helps, and supports humanitarian and social tasks, as well as the political stability of the governor of West Java as the regional head. West Java Quick Response in addition to being an innovation in West Java regional government in an effort to realize Good Governance. Although the position JQR cause problem, but it is also an effective step in the politics of the governor of West Java in carrying out leadership as the regional head in the government of West Java.
\end{abstract}

Keywords: The Auxiliary Organs; Local Government; Good Governance

How to Cite: Abdillah, A., Deliarnoor. N. A., Yuningsih, N. Y., \& Fatmawati, F. (2020). The Position of Auxiliary Organ in Government System of West Java Provincial Government. Journal of Contemporary Governance and Public Policy, 1(2), 67-81.

Permalink/DOI: https://doi.org/10.46507/jcgpp.v1i2.11 


\section{Introduction}

In the Reformation and in the amendment of the Constitution 1945 as much as 4 (four) times, as an attempt to seek the ideation of the need for Democratic in Indonesia, the consequence is the birth of State Auxiliary Organs (Supporting institutions/auxiliaries) which is another form of government practice in Indonesia (Iswandi \& Prasetyoningsih, 2020; Nurtjahjo, 2017). This can be said as part of the principle of Sharing Of Power (Power share). The term State Auxiliary Organs is interpreted as serving institutions, helping institutions, auxiliary institutions, and supporting institutions. The term is given as a differentiator from major institutions (State Main Organs) such as parliamentary, governmental, and judicial institutions (Triningsih \& Mardiya, 2018).

By the Development Spirit (spirit of development) of the Law of local government and regional autonomy, Law No. 23 of 2014 about the local government of the change in Law No.32 of 2004 about local Government is the development efforts of the district is expected to be able to maximize the work of government agencies in identifying problems, plan solutions and implement development in the region. In 2019 Indonesia had 34 provincial government, 416 district government, and 98 of the municipalities government.

In the regional government, the establishment of SAO (States Auxiliary Organs) is the necessary to accomplish the task quickly. In SAO studies this symptom may show less effective and efficient of regional executive institutions i.e. head of regional government as well as regional device organization commonly called $O P D$. It can also because of lack of trust to the institution/agency that existed so that it is formed a new institution such as State Auxiliary Organs (Basarah, 2014).

At least, the birth of some institutions such as if at the central government level, there is a National Human Rights Commission (NHRC), the Independent Broadcasting Commission (IBC), the General Election Commission (GEC), the Corruption Eradication Commission (CEC), the National Ombusman Commission, and the National Commission for Child Protection (NCCP). It shows the existence of something new in the constitutional practice of the Republic of Indonesia (Huda, 2007). If at the level of local government, there is Ad-Hoc (SAO in temporary institution type) such as there is $T P 2 D$ in the local government of South Sulawesi, there is TGUPP in Jakarta provincial government, and there is Jabar Quick Response in the West Java provincial goverment.

The establishment of State Auxiliary Organs or supporting institutions in Indonesia has different legal bases which are based on the Basic Law (Constitution), Presidential Decree (Keppres), or Regional Head Policy, as well as those established due to international obligations. When examined further, there are a variety of reasons that are behind the birth of this State Auxiliary Organs. For example, the establishment of Corruption Eradication Commission (CEC) through Law No. 30 of 2002 then revised into Law No. 19 of 2019 about the Corruption Eradication Commission because the government agency that exists both prosecutors and police have not functioned effectively and efficiently in dealing with corruption (Deliarnoor, 2018). also in the regional government of South Sulawesi, hence formed TP2D as a auxiliary institution in building 
acceleration of regional development in South Sulawesi.

The State Auxiliary Organs is an institution established on the needs of the government tasked with assisting the work and activities of the government to improve the quality of public services as well as to increase effectiveness and efficiency in the central and local government systems, Then look at the increasingly efficient government bureaucracy in meeting the increasing demands of the community then the establishment of support/auxiliary institutions (Ayu, 2009), which is not only at the central level but also at the level of the regions in carrying out the duties of the government to serve the community, whether the form of Executive Agency, Independent Agency, and Ad-Hoc which are all State Auxiliary Organs (Satriawan \& Mokhtar, 2019).

The independent institution (State Auxiliary Organs) is not only in the central government but also in the local government that helped support the works of Government but on the other hand, the presence of independent institutions can also be a challenge, it is because of the problems of the establishment of supporting institutions or helpers as discussed previously, can be seen the phenomenon of growth of independent commissions and the executive Agency and Ad-Hoc as The State Auxiliary Organs which is coloring the central government until local government (Asshidiqie, 2006).

Development Innovation West Java provincial government (good governance) on 18 September 2018 is the establishment of governmental auxiliary institutions (Auxiliary Organs) Jabar Quick Response by the governor of West Java province, that aims to realize a fast responsive government by the complaints, the heartpouring of West Java society, and also as efforts to closer with the community. It is also as innovation of the Implementation movement EGovernment and Good Governance for the challenge of the millennial era in 21 century, such as complaints, health, social assistance, education, development of village, regency and municipalities.

Every auxiliary or supporting institution formed by government policy is tasked to carry out government duties whether it is in the form of executive power i.e. executive agency, people's power i.e. independence Agency, or supporting institution in the form of a certain period of time such as Ad-hoc is state Auxiliary organs (Ayu, 2009). As revealed by Jimly Asshidiqie said As in development in the Britain and United States, the auxiliary or supporting institutions are still in the realm of executive power and are outside the power of executive, legislative, or judicial. In general, the establishment of independent institutions (Auxiliary Organs) is driven by the fact that the bureaucracy in the government environment is assessed can no longer meet the demands of public service with an increasing quality standards and it is expected to be increasingly efficient and effective (Asshidiqie, 2006).

Jabar Quick Response is a channel of humanitarian complaint for the people of West Java. Jabar Quick Response is present to provide solutions or first aid for problems that are humanitarian and emergency in the West Java provincial government. In 312 working days, There was recorded that Jabar Quick Response (JQR) managed to crack down on 404 complaints, also since the launched of JQR by Governor of West Java, there were 57,187 complaints by the public, and JQR has responded 34.364 complaints. Health 
complaints are the most problems by JQR until July 31, 2019. From 404 complaints handled, the health problem are 281 complaints, then education is 78 responses, 16 acts for collapsed house, 8 acts for broken bridge, 10 acts for poor nutrition, 1 acts for electric, and 10 acts for disaster (Adam, 2019).

Figure 1. Scheme about Jabar Quick

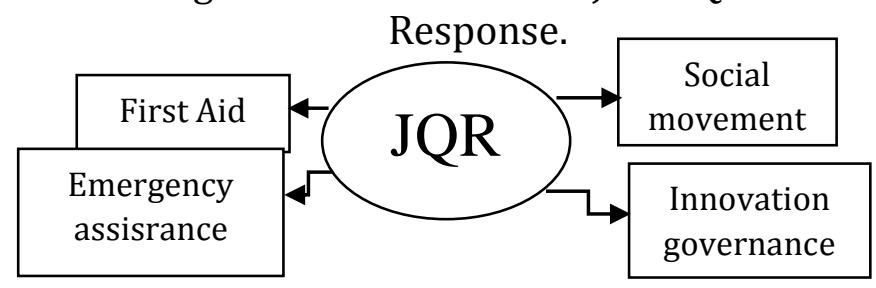

Source: HUMAS JABAR Kepala Biro

Humas dan Keprotokolan Setda

Provinsi Jabar, Herman Syah: 2019.

Figure 1 explains that Jabar

Quick Response (JQR) is a supporting institution in the West Java regional government that focuses on first aid activities (First Aid), emergency assistance, social humanitarian movements (social Mevement), and JQR as well as Government Innovations (innovation governance) in West Java regional government.

Jabar Quick Response (2018) which was formed on the initiative of West Java governor as a manifestation of its vision and mission, it has no coordination with the Government institutions directly and organized in the government system, but only directly coordinate and responsible working with the governor of West Java as the head of the region. When see from the State Auxiliary Organs Review, JQR is included in the type of executive Agency (executive power), the supporting institution that carries out the role of government roles in public service to the community by conducting fast-paced response to the problems that exist in the society. Furthermore, JQR not only included in the executive type agency, but also included in the Independence Agency, as well as ad-hoc, if we see JQR work activity in the middle of the society and volunteers who are in JQR non official also known as come from the public community and the period of time JQR may only exist in the period of Governor of West Java Ridwan Kamil.

From the existence of Jabar Quick Response in West Java provincial goverment, appeared discussion on the problem of his status as State Auxiliary Organs in the governance system review of the institution carried out its functions, duties, and obligations as a Government assistant around the existing government agencies. It is also about the tenure of JQR members (as supporting institutions), as well as relationships with existing institutions, and until the problem of budget that is certainly every government institution in its activity require a budget for the establishment of their respective duties. As in the DIPA (the list of the implementation of the budget), there are those who have their own budget and some are on the budget of institutions, such as the Kompolnas (National Police Commission) which is still on the budget of the State Budgets through Head of Indonesia Police.

Understanding and Explaining a State Auxiliary Organs or Independent institution in a research study using the principle are, 1.Policy Principles, 2.Financing/ Budgeting Principles, 3.Organizational Work Principles, 4.Tenur and Substitution Principles (Ayu, 2009).

In Policy Principle, JQR until now has not had Letter of Dicision or clear basic policy because since launched JQR on 18 September 2018 in Gedung Sate until today, many Members JQR not know more about the work letter of decision as 
administration procedure for the work legality of JQR.

And the principle of turnover and tenure, JQR members were formerly successful team Ridwan Kamil when becoming the candidate for governor of West Java and when elected for a period of 5 years. Two months after the inauguration, Ridwan Kamil was performed recruitment JQR members from the success team Ridwan Kamil, though can to the perfection of JQR by the recruitment of members should prioritize the quality and professionalism of prospective members.

With the background outlined above, the author raised to review the existence of the state Auxiliary organs status in the regional government in the West Java Provincial Goverment by focusing on the institution that was inaugurated on September $18^{\text {th }}$ 2018 by West Java governor or Jabar Quick Response.

\section{Research Methods}

Qualitative approaches are used to describe a meaning, one of the qualitative traits that is descriptive, providing an objectively precise, precise explanation of the true state of the object examined through data collection. Qualitative data is data in the form of words, not in the form of numbers (Moleong, 2005).

The type of data used in this study is divided into words and actions, written data sources, photographs, and statistics. A qualitative research by Creswell (2012), a qualitative method is a research procedure that generates descriptive data of written or spoken words from people and behaviors observed (Creswell, 2012).

Accordingly, Sugiyono (2007) says that qualitative research is a certain tradition in social sciences that fundamentally relies on human observation in its own region and relates to such people in its language and its terminology, its purpose in general there are three kinds of inventions, conception, and development.

The perpetrators of interest in the local government system in West Java related to Jabar Quick Reponse is the primary data source in qualitative research which the words and actions obtained from informants through interview techniques, then secondary data that is documents that can strengthen the results of research (Ramdhani, 2019). The sources of data in this study are people and government agencies that are used as a reference for authors to collect the desired data according to the problem and focus of the research. The data sources used in this study are legislation, literature, notes, documents, interviews and articles (Moleong, 2005).

Data analysis technique using Miles \& Huberman model (Sugiyono, 2007). states that Data analysis technique is an interactive and continuous activity from the beginning of the research until completion, so that the research is at saturation point. There are two data analyses used, among them: policy principles and non-parliament or tenure principles.

\section{Result and Discussion}

The Rapid Response Team (JQR) which captures the complaint of society, through the Complaint Channel, so that the people of Wet Java will get quick and precise handling. The Complaint Channel should be integrated with complaints channel that is located in the District/municipalities. In addition, JQR as a Support System from various citizen complaints channels that have existed, so that its response can be 
done quickly, precisely, and accurately. JQR as the bridge of the related parties; Citizen-GovermentalGovernment with collaborative spirit to produce first aid decision or solution. (First Aid) (Jabar Quick Response, 2019).

In JQR (Jabar Quick Response, 2019) Explained the elements involved in touch with JQR as a program and the implementation team vision and mision the governor of West Java related to humanitarian problems as we know this team spread in 27 district or municipalities in West Java, the following are:

a. The people of West Java as rapporteur aree all elements of society listed and citizens in the regency or city of West java province, through a complaint hannel called Jabar Quick Response (JQR).

b. The Quick Response Team (JQR) is a quick solution organisator formed by the government of West Java as a team that carries out the function: the recipient of complaints of survey implementation verification and problem solving through rapid enforcemement.

c. The aid provider (governmental) is a variety of elements that can provide assistance for the resolution of social problems in the community of district/ municipalities in West Java, including public through private donation and government grats/CSRgovernment through $A P B D$.

d. Volunteers are social workers who give time and energy to assist the implementation of JGR program.

In JQR (2019), to know more about the Jabar Quick Response related tasks, functions and work activities of Jabar Quick Response (JQR), the following are:

a. As recipiencts of grievances or public complaints through electronic and conventional media.

b. Separated emergency issues based on complaints objects category and priority scale.

c. Verify the complaint object.

d. Responding to complaints through field survey of complaints objects.

e. Management of humanitarian and social issues with collaboration principle, along with related parties.

The scope of Jabar Quick Response (JQR), there are some became the focus of the suppressoreness that is in the standard operational procedures (SOP) JQR among others: first, emergency health or pain. Second, break access education. Third, hunger $\&$ poor nutrition. Fourth, lifethreatening emergency house. Fifth, emergency electrically of isolated village. Sixth, emergency bridge. Seventh, the Corpse place. (Jabar Quick Response, 2019).

Jabar Quick Response (JQR) is a channel of humanitarian complaint for the people of West Java. Jabar Quick Response is present to provide solution or first aid for humanitarian and emergency problems.

In the decision letter by the Governor of West Java regarding the status and position of Jabar Quick Response (JQR) is a complaint organization, a helper organization, or supporting organization (The Auxiliary Organs) outside the local government of West Java. It helps in the task of \& the function of local government of West Java that focuses more on humanitarian problems in the mission and vision of West Java Governor. 
To more clearly see the position of Jabar Quick Response in the system of Regional government of West Java province, first we can see from the JQR organizational structure and secondly also in the decision letter of West Java Governor on 15 November 2018 Number: 465.05/kep. 1215-Humaspro/2018 about the Rapid response team of West Java.

By referring to his opinion Miranda Risang Ayu (2009) in understanding and explaining the position of the supporting institution (State Auxiliary Organs) which is independent or outside the main institutions of government such as executive, legislative, and judicial institutions in the local government system by looking at two principles namely policy principles and principles non-parliament/tenure From several criteria that determine by looking at the position of Jabar Quick Response that exists in the environment of the Regional Government of West Java province as an auxiliary institution in realizing the mission vision of the governor of West Java as the head of regional.

\section{Policy Principle}

In the policy principle is the basis of regulations that explain the status and status of Jabar Quick Response in the system of regional government in West Java. In policy principle, the basis of regulations describing the status and status of Jabar Quick Response in the system of regional government in West Java, as we know JQR until today has not had a clear Decision Lettel (DL) or clear policy to explain related coordination with other institutions and about budgeting, membership and tenure in JQR. DL works only as the administrative procedure for the legality of JQR work since the establishment of JQR on 18 September 2018 in Gedung Sate.

According to what was said by West Java Governor, Ridwan Kamil ${ }^{1}$, DL issued by Governur West Java as a coach in JQR are

"Policy base of Jabar Quick Response is Decision Letter of the West Java Governor No.465.05/Kep. $\quad 1215$ Humaspro/2018 about Rapid Response Team of West Java that was changed to the decision of the governor of West jawa No. 465.05/ Kep.1005-HUMASPRO/2019 about Quick Response team of West Java"

Moreover, it was also conveyed by Setiawan Wangsaatmaja (plt Skeda Jawa Barat 2019) ${ }^{2}$ as the director of JQR that:

"Posistion of JQR in the goverment system is an independent institution outside the main goverment of West Java Provincial Districts"

Also as the head of Public Relations Bureau \& the Protocol, West Java ${ }^{3}$ said :

"JQR constraints in budget also problematic in the rule of JQR policy that makes contact with government agencies West Java Provincial such as the service does not run in accordance with expectations or it is mean difficult, which commonly required quick coordination to work JQR. It is because of the unsteady rules hindered with existing bureaucracy system"

\footnotetext{
${ }^{1}$ In Decision Letter (DL) West Java Governor No.465.05/Kep.1005-Humaspro/2019

${ }^{2}$ Interview with Dr. Ir. Setiawan Wangsaatmaja ipl. SE., M.Eng. located in Gedung Sate at January $30^{\text {th }} 2020$.

${ }^{3}$ Interview with Ir. Hermansyah, M.Si
} 
If we see what is the basis of the policy of Jabar Quick Response in the work activity JQR only based on the decision letter of the West Java governor No. 465.05/KEP. 1005HUMASPRO/2019 on Quick Response Team West Java which only describes the functions of Jabar Quick Response such as: First, fast response Team West Java hereinafter called Jabar Quick Response with its personnel composition and task description as stated as part inseparable. Second, Jabar Quick Response as mentioned in the first dictum has a task to facilitate in order to accelerate the handling of humanitarian and social problems in the region of West Java province which is emergency. Third, as acceptance of complaints or grievances of people in the of West Java province through electronic and conventional media. b. Screening of emergency problems based on complaint object category and priority scale. c. enforcement through verification and validation. $d$. humanitarian and social problems. e. coordination with the devices of the provincial district of Jabar and other related parties. and f. collaboration with related parties in order to handle humanitarian and social issues. (DL governor of West Java, 2018:3)

In south Sulawesi also formed similar institutions such as Jabar Quick Response in the Government of West Java, Governor of South Sulawesi, Nurdin Abdullah formed the Regional Development Acceleration Team (RDAT) Sulsel, which one of the objectives is to ensure that all programs are integrated and synergized well, so that RDO (Regional Device Organization) does not go its own way. the existence of RDAT is not more or less the same as the existence of Jabar Quick Response in the Government of West Java is very helpful and needed by regional heads in the governance of local government and realize the visions of the government.

To get to know the RDAT form of the Governor of South Sulawesi can be seen in the organizational structure of TP2D, in the decision letter (DL) of the Governor of South Sulawesi No.2537/IX/2018 about RDAT The team consists of 24 people led by Prof. Dr. Ir Yuran Jusuf M.Si. following the complete arrangement of RDAT form Nurdin Abdullah and Sudirman Sulaiman, chairman, namely; Prof. Dr. Ir Yuran Jusuf M.Si. Secretary; Redra Darwis ST (infrastructure). Members; Prof. Dr. Rudy Djamaluddin (infrastructure), Prof. Dr. Ir Syamsu Alam Ms (education), Prof. Dr. Sangkala (health), Dr. Jayadi Nas MSi (government), Dr. Alwi Rahman MA (cultural), Dr. Ir Abd Hans Bahrun MSi (agriculture) Dr. Sukriansyah SH MH Law \& Human Rights), Drs. Akib Fattah (acceleration of selayar development), Fahmi islami S.Sos (government), Andi Rasdi Sumange Amd (government), Bustam Tin (acceleration of Luwu Raya foaming), Dr Ir Zuryati Djafar MT (engineering) Dr Ir Mimi Arifin MT (agriculture), Munawir Akil ST (agriculture), Moch Anugrah NPB ST (architecture), Muh Hasanuddin Taiben Skom (IT/Teknik), Arman ST (engineering), Arif ST (engineering), Andrew Marsha Mulia SH (law), Nikita Andilolo SE (media), Zulham Arief SH (creative).

This is like the Governor's Team for the acceleration of development (TGUPP) of the Provincial Government of DKI Jakara which was created by the Governor of DKI Jakarta Anies Baswedan based on governor regulation No.16/2019, which has duties and authority; First, carry out the abomination and analysis of the Governor's policies. 
Second, give consideration, advice, and input in the preparation and implementation of the governor's policies. Third, carry out monitoring and implementation of the governor's office. Fourth, receiving information from the public in the implementation of the governor's policy. Fifth, carry out the assistance of the governor's priority program implemented by the regional device. Sixth, carry out monitoring of the planning and budgeting process by regional devices. Seventh, carry out mediation of regional devices and related parties in order to resolve the obstacles to the implementation of the priority program of the governor and deputy governor. Eighth, carrying out the duties given by the governor and deputy governor. ninth, report and account for the performance of his duties to the governor.

The distinguish TGUPP DKI Jakarta with JQR West Java Provincial Government,we can see from the policy basis, from the basis of this policy which slightly explains about the position, authority, and the function of supporting institutions such as TGUPP Provincial Goverment DKI Jakarta and JQR Government of West Java, if TGUPP Provincial Government of DKI Jakarta based on Governor Regulation No. 16/2019 about The Governor's Team for the acceleration of development and JQR based only on decree $(S K)$ of the governor of West Java No. 465.05/Kep.1005-PRASPRO/2019 on West Java Rapid Response Team. If we look in the legal hierarchy of governor regulation policy to be the highest policy in an area outside the local regulations (perda), see Jabar Quick Response based only based on decision letter governor of West Java is very affecting the position and status of JQR in the west Java provincial environment.
It is a problem related to the position of JQR which is still not concrete in the system of government of West Java province although in the status of institution has been said by the Plt. The Secretary of The Government of West Java is an Independent ${ }^{4}$ institution but if looking at the organizational structure and Decision Letter of West Java Governor that JQR is not an independent institution but an institution of The Local Government of West Java, if we see that budget come from the West Java Budget as well as its non-ASN and ASN membership.

Figure 2 explains that in the formation of JQR in West Java Regional Government, namely in the planning based on the instructions of the regional head, the inauguration was also carried out by the regions as well as socializing to the people of West Java. The human resources in JQR come from ASN elements and Non ASN elements. The JQR funding comes from the APBD and CSR funds. Until the implementation of the JQR it followed the will of the regional head, namely the governor of West Java.

It can be said that Jabar Quick Response still requires a clear policy and policy basis that is used as a policy principle in addition to assisting in effective relations and coordination with the West Java Regional Government, as well as explaining the status and position of JQR as an auxiliary organs in the West Java government system. In order to realize good governance in the government system in West Java, each institution needs a clear policy basis governing the status of institutions, functions, and legalities of the work of institutions including Jabar Quick Response in the West

\footnotetext{
${ }^{4}$ Interview With Dr. Ir. Setiawan Wangsaatmaja ipl. SE., M.Eng.
} 
Java Provincial Government. so that the realization of a government that is accountability, transparency, effective and efeisen, until there is a good rule of law or we used to call it Good Governance.

Figure 2. Formation Step of Jabar Quick Response

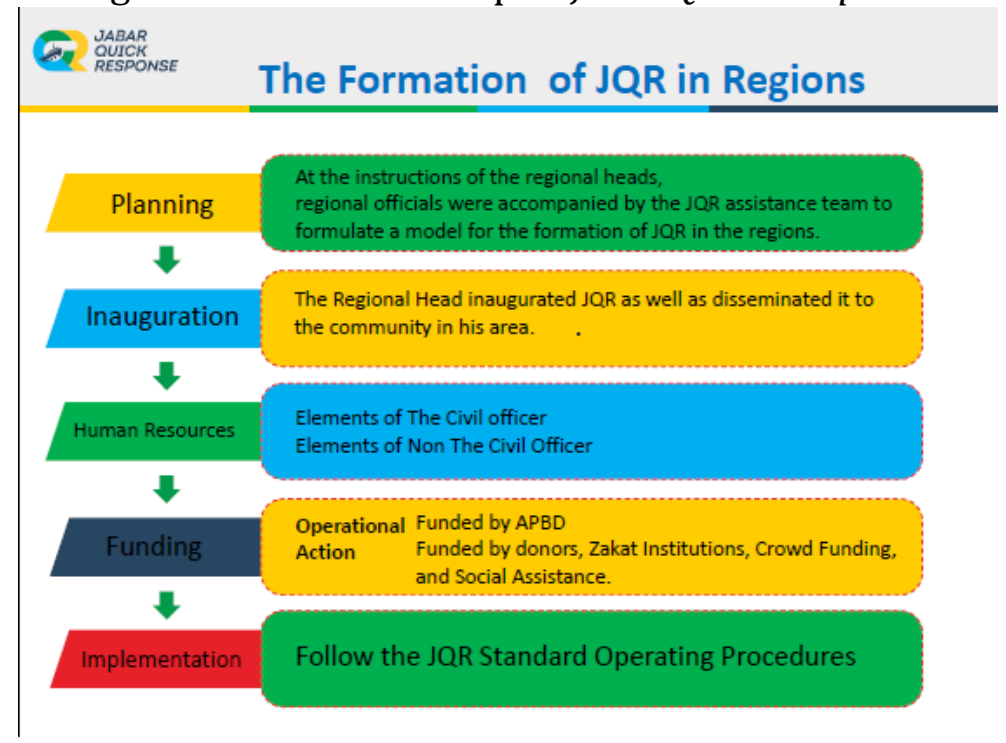

Source: in the program \& Jabar Quick Response Profile: 2019

\section{Tenure or non-political parties Principle}

The principle of nonparliamentary namely Jabar Quick Response members such as members in Office JQR is a member of PSI (political party) and legislative candidiate of Election 2018 from PSI (Indonesian Solidarity Party) if we look at from the theory State Auxiliary Organs, SAO should be that the use of JQR is not from the parliament to maintain the Independence of the interests of government aid agencies such as Jabar Quick Response in the environment of west Java regional government.

As said by JQR daily Chairman, Bambang Trenggono ${ }^{5}$ related to Jabar Quick Response, namely:

"Jabar Quick Response is not only a channel of complaints about humanitarian and social problems in the West Java environment but also JQR as

\footnotetext{
${ }^{5}$ Interview with Bambang Trenggono located in Gedung Sate on Thursday, January $30^{\text {th }} 2020$
}

the political stability of the Governor of West Java."

It is also said by The Local Government of West Java, Setiawan Wangsaatmaja ${ }^{6}$ namely:

"Jabar Quick Response is not only an Innovation of the Government of the Governor of West Java, but also a compassionate element of all stekholders, stakeholders, and political stability."

So, it can be said that Jabar Quick Response is in addition to realizing the humanitarian and social missions of the west Java regional government that provide humanitarian and social assistance to the people of West Java, JQR is also an element of building, maintaining, and rehabilitating the political power of the governor of West Java in leading the way of the West Java regional government, JQR is also a charging place for Ridwan Kamil political

\footnotetext{
${ }^{6}$ Interview with Dr. Ir. Setiawan Wangsaatmaja Dipl. SE., M.Eng, located in Gedung Sate on Thursday, January $30^{\text {th }} 2020$.
} 
supporters, as said by Annisa Wisdipangesti Adjie ${ }^{7}$ and also recognized by Yosan Mariani ${ }^{8}$ as the JQR Team in the field of services and complaints, namely:

"Jabar Quick Response
members are also from
Political Parties such as The
Solidarity Party of Indonesia,
one of them coordinator of JQR
Team in the Field of Service
and complaints, there is a
legislative candidate in 2018
from PS."

"Jabar Quick Response as the Governor of West Java program as well as a container to accommodate the successful team of the 2018 election governor of West Java Mr. Ridwan Kamil."

It can be inferred from the statements and information conveyed by the informants above if we see the principle of not a political party to explain related supporting institutions and aides in the environment of the Local Government of West Java. Thus JQR does not meet that principle. Why is it important that the basic aspects are not political parties of supporting institutions or aides such as JQR in the government environment, especially in West Java, namely to maintain the independence of the institution as an independent institution that moves to the mission of humanity even though the fact as previously said JQR is also as the political stability of the governor of West Java.

The presence of Jabar Quick Response should be able to take from the professional element and

\footnotetext{
${ }^{7}$ Interview with Annisa Wisdipangesti Adjie located in Gedung Sate on Friday, January 10th 2020

${ }^{8}$ Interview with Yosan Mariani located in Gedung Sate on Friday, January 10th 2020
}

competence of the expertise not from political parties. but because the political purpose of the interests is so different that it is not good that the mission that began it was used as a political resource of its elites. We know that in political principles every political support of power has a price to pay, such as the presence of Jabar Quick Response outside its humanitarian and social missions as well as the political cost of power from Ridwan Kamil as the winner of the 2018 West Java regional election which became the Governor of West Java.

And the principle of turnover and tenure of JQR members is that the success team of Ridwan Kamil when he became the Candidate of the Governor of West Java and when elected for a period of 5 years 2 months after the inauguration of RK was done the recruitment of JQR members from ridwan kamil success team, when it could be for the ideal JQR for the recruitment of members should prioritize the quality, competence and professionalism of prospective members.

From the principle of this tenure Jabar Quick Response as said by JQR Daily Chairman, Bambang Trenggono ${ }^{9}$ yaitu:

"The presence of Jabar Quick Response only follows the Term of the Governor of West Java, Mr. Ridwan Kamil, a period of 5 years of tenure as governor of West Java."

The periodization of tenure Jabar Quick Response's institutional and organizational period follows the 5-year tenure periodization the governor of West Java which is 5 years each as governor of West Java, it can be said that JQR if it follows the policy of Letter Decision Governor of

\footnotetext{
${ }^{9}$ Interview with Bambang Trenggono located in Gedung Sate on Thursday, January, $30^{\text {th }} 2020$
} 
West Java. Today JQR only existed 5 years in Ridwan Kamil period as governor of West Java. it could be that the upcoming governor of West Java Jabar Quick Response has been not in the local government system of West
Java. but it does not close the possibility that JQR still exists even on the basis of a more complete policy and conperehension related to its position in the system of central java.

Figure 3. Time Schedule of Jabar Quick Response

\section{Time Schedule JABAR \\ Jabar Quick Response}

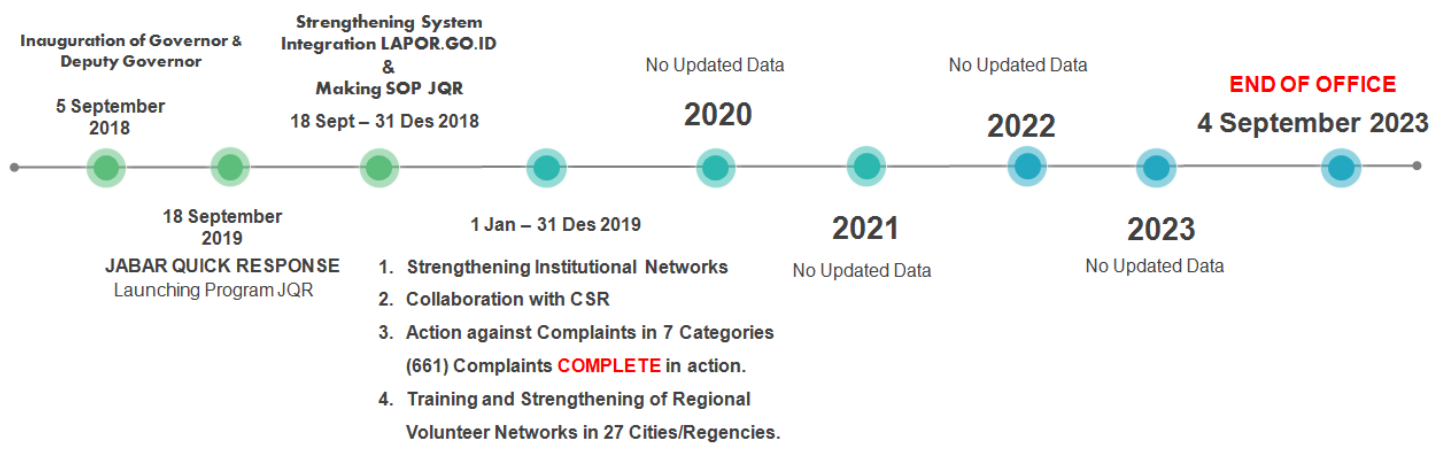

Source: document of Jabar Quick Response: 2019

In Figure 3 the timeschedule Jabar Quick Response (2019) describes the working time phase of JQR which follows the tenure of the governor of West Java since his appointment until the end of the term of the Governor of West Java in 2023. We know the inauguration of the governor and deputy governor of West Java from wednesday, September 5, 2018. Then the launch of Jabar Quick Response tuesday, September 18, 2018. From September 18, 2018 to December 31, 2018, the strengthening of the Lapot.go.id integration system and the creation of Jabar Quick Response Procedure (SOP) Oprasional Standard. From January $1^{\text {st }}, 2019$ to December 31 ${ }^{\text {st }}$, 2019, first, the strengthening of institutional networks. Second, cooperation with CSR. Third, the suppression of 7 categories of Incoming Complaints (approximately 661 complaints were completed in 2019). And Fourth, the inauguration and strengthening of the network of regional volunteers in 27 cities / districts in West Java. Until September $4^{\text {th }} 2023$ the end of the term of Governor of West Java.

The important thing is Jabar Quick Response is an independent institution outside the main government agencies in the west Java regional government whose position as an auxiliary institution in realizing the vision-mission of the governor of West Java on humanitarian and social issues of an emergency nature with the principle of collaboration and innovation according to the direction of the governor of West Java Today. 
Figure 4.

Human Resources in Jabar Quick Repsonse

\section{Human Resources of Jabar Quick Response}

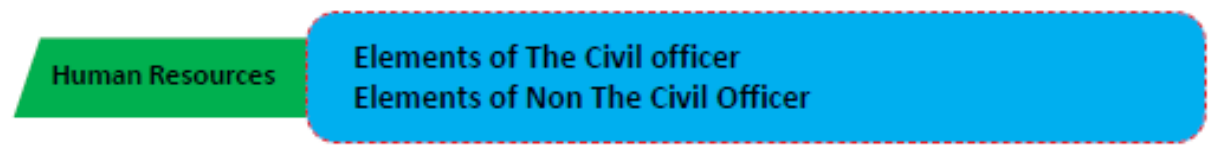

Source: in program \& profile of Jabar Quick Response; 2019

In Figute 4, there are 2 elements in JQR Human Resources, namely from ASN Elements who work in the West Java regional government as well as from Non ASN, namely recruiting JQR members, if we look at the SK and the background of JQR members, almost all JQR members come from the success team. Ridwan Kamil when nominating for governor of Java and Bara in the last 2018 regional elections and part of it from the ASN element for the administration of West Java province.

Below we can see the background to jabar quick response members who are mostly non ASN that came from Ridwan Kamil's successful team when running for governor of West Java in the last election, taken from the Decision Letter (DL) Jabar Quick Response year 2018 Number: 465.05/Kep.1215-Praspro/2018 about the West Java Rapid Response Team.

There is founder, Governor of West Java and Vice Governor of West Java. There is Director, regional secretary of West Java Province. Also Advisors exist:; First, Aat Soeratin (social and humanitarian activist from Wanadri). Second, Antonius Harso Waluyo (Business World of Real Estate Indonesia). Third, Ir
Denda Alamsyah, S.T (Community Organization of Siliwangi Youth Force). Fourth, DR. H. Den Nurdiana Hadimin, M.So. CFrA (a community organization of scouts). Fifth, Galih Donikara (social and humanitarian activist from Wanadri). Sixth, Juwanda, S.T. (Information Technology Expert from ITB). Seventh Roni Lukito (Business World Element of the Eiger). Eighth, dr. Siska Gerfianti, M.H.Kes, Sp.D.L.P (health activist from Bandung Health Office). Ninth, Tendi Ixdiana (social and humanitarian activist from Skygear). Tenth, Dr. dr. Tri Wahyuni Murni SP. BTKV. MH Case. (health activist from RSHS).

Then in charge of Jabar Quick Response, there is the Head of The Bureau of Public Relations and Regional Secretariat Protocol of West Java Province. The Chief Executive of Jabar Quick Response is Bambang Trenggono (social and humanitarian activist from Jabar Juara Volunteer foundation). Vice Daily Chairman of JQR, Mochammad Saban Hanief (social and humanitarian activist from Bandung Jurnal Social Institute). JQR Secretary, head of media and information services section of the Bureau of Public Relations and Regional Secretariat Protocol of West Java Province. 
Further on oprational technical in structural organization JQR exists; First, secretariat, there is Meta Rahmani Karaeng Ngada (social and humanitarian activist from Jabar Juara volunteer foundation). Second, there is Karlina Berlianti Pertiwi (social and humanitarian activist of Jabar Juara community movement). Third, there is Diani Rezki (Social and humanitarian activist from Jabar Juara volunteer foundation). Fourth, Lati Komariah (social and humanitarian activist from Maharindu).

In the field of Cooperation, Law and Advocacy, there is a Coordinator, namely the Head of Cooperation Section of the Government Bureau and Cooperation of the Regional Secretariat of West Java Province. Then Deputy Coordinator; First, head of legal aid and human rights at the Law and Human Rights Bureau of the Regional Secretariat of West Java Province. Second, Mohammad Iqbal Audah (social and humanitarian activist from BKPRMI West Java). Members exist; First, Abdul Wahab (Social and humanitarian activist from Yayasan Solusi Bandung Bersama). Second, Ries Deni Saeful Hamdani (Social and humanitarian activist from East Bandung Community Front). Third, Samsu Yusawisana (Social and humanitarian activist from Jabar Juara Volunteer Foundation).

$$
\text { In field of Media, }
$$

Publication and Technology Information, there is a Coordinator namely the Head of Publication, Documentation and Coverage Section of the Bureau of Public Relations and Protocol of the Regional Secretariat of West Java Province. Then Deputy Coordinator, there is Suhendrik (Jawa Pos Journalist). in the Member; there is First, Titus Wahyu Wibowo (information technology activist from Jabar Juara volunteer foundation).
Second, Zamzam Yassari R A (information technology activist from Jabar Juara volunteer foundation). Third, Aditya Sanggaputra (Information Technology Activist from Jabar Juara Volunteer Foundation). Fourth, Fazhal Darul Farhi (information technology activist from Jabar Juara volunteer foundation). Fifth, Typhoon Sugara (Social Media Activist from Jabar Juara volunteer foundation). Sixth, Stevano Febi Ananda Pratama (Social Media Activist from Jabar Juara Volunteer Foundation). Seventh, Ganjar Darussalam (Social and humanitarian activist of Dinamic Nationalist Community).

In operations and logistics field, there is a Coordinator, namely the Head of The Problem Disturb and Social Empowerment Section of the Social Services and Development Bureau of the Regional Secretariat of West Java Province. Deputy Coordinator there, there is First, Head of Health Services at the Local Government Health Office of West Java Province. Second, Head of Emergency and Logistics at the Regional Disaster Management Agency of West Java Province. Third, Head of Housing at the Department of Housing and Local Government Settlements of West Java Province. The fourth, Reggi Kayong Munggaran (Social and humanitarian activist of bikers brotherhood and fir house). And in the Member, there is the First, Ashwin Hermawan Suganda (social and humanitarian activist of Buah Batu Club). Second, Legimin Trismaladi (social and human activist of the Bikes Brotherhood). Third, Muhammad Irvan Hilmu, A.Md (Social and Human Rights activist from Jabar Juara Volunteer Foundation). Fourth, Rian Zakaria (Social and Humanitarian Activist of Jabar Juara Volunteer Foundation). Fifth, Diki Winandi (social and humanitarian 
activist from bandung bersama solution foundation). Sixth, Yudi Nuralim, A.Md (social and humanitarian activist from Jabar Juara foundation). Seventh, Asep Koswara (social and humanitarian activist from Bandung Bersama solution foundation). Eighth, Erwin Permana (Social and Humanitarian Activist from Jabar Juara Volunteer foundation). Ninth, Gilang Agas Triansyah (Social and humanitarian activist from Jabar Juara Volunteer foundation).

In the field of complaint services, there is a Coordinator, namely the Head of Information Services Subsection at the Bureau of Public Relations and The Department of The Regional Secretariat of West Java Province. Deputy Coordinator, there is Yosan Mariani (Social and humanitarian activist from jabar juara community movement foundation). In members, there is; First, Rini Marlina (Social and humanitarian activist from Jabar Juara Community Movement Foundation). Second, Urfah Masrurotin Syarifah (Social and humanitarian activist from Jabar Juara Community Movement Foundation). Third, Kurniawan (Social and Humanitarian activist from Jabar Juara Community Movement Foundation). Fourth, Annisa Widipangesti Adjie (Social and Humanitarian activist from Jabar Juara Community Movement Foundation). Fifth, Nizar Abdussalam (Social and Humanitarian activist from Jabar Juara Community Movement Foundation

In Network and Volunteer field, there is a Coordinator, namely the Head of Social Rehabilitation at the Social Service of the Local Government of West Java Province. In the Deputy Coordinator, there is Amin Nurdin (Social and Humanitarian activist from Pemuda
Persis). In the members, there is the First, Hari Brahma (Automotive Activist from Honda Klasik and Rumah Cemara). Second, Sani Sandyani (Social and Humanitarian activist from Jabar Bersatu Foundation). Third, Gina Afrianti Wulan (Social and Humanitarian activist from Wanadri). Fourth, Fatur Rahman (Automotive Activist from of Honda Klasik and Rumah Cemara).

The reason for choosing a successful team to fill membership of Jabar Quick Response as for political stability is not the blame, but also to maintaim quality, and the independence of JQR's objectives should consider the professionalism and integrity of the members that lead to the institutional quality of JQR and also consider the competence and feasibility of JQR, if we see, the budget used from Regional Revenues and Expenditures Budget, that we know is the mandate of the West Java people which is used as the best as possible for the birth and inner life of West Java society.

This is the same as the South Sulawesi Regional Development Acceleration Team (RDAT) which was created by The Governor of South Sulawesi, Nurdin Abdullah in devision letter (DL) No. 2537/IX/Year 2018 on the Regional Development Acceleration Team (RDAT) of South Sulawesi which amount of 24 members. The 24-member team is led by Prof Dr Yusran Jusuf MSi. The expectation, the presence of RDAT in the local govern ent of South Sulawesi as a form of government efficiency in the Sulsel Provincial Government. Who was formed to fill Nurdin Abdulah's successful team while as a Candidate for Governor of South Sulawesi in 2018. So, it is many modes in helping supporting institutions or independent institutions but also it's an effective 
political step to perpetuate the power of always the head of government.

Explaining that Jabar Quick Response's position in the West Java regional government system in addition to government innovation and humanitarian movement in realizing the vision of the government mission also raises problems in practice, such as unclear policy basis, overlapping coordination, to the source of budgeting from the West Java Budget, including in the objectives of its work on the one hand as an effort to address humanitarian and social emergencies in West Java but also as a political institution to maintain the political electability of the Governor of West Java.

\section{Conclusion}

Jabar Quick Response as an auxiliary and supporting institution in the Local Government system in West Java. First, based on the policy principle that is Jabar Quick Response can be said to still require a clear policy and basic basis that is used as a policy principle other than to assist in effective relations and coordination with the Regional Government of West Java as well as explain the position of Jabar Quick Response as an auxiliary and supporting institution (The Auxiliary Organs) in the West Java system of government to realize the mission vision of the governor of West Java. Second, the principle is not a parliament. Explaining that the presence of Jabar Quick Response in the West Java Area of The Region in addition to as a humanitarian and social channel as well as the political stability of the governor of West Java, as an effective political step in running the wheel of leadership in the regional government of West Java province.

\section{Acknowledgements}

The author's gratitude goes to the West Java Provincial Government, in this case the Head of the West Java Provincial Public Relations Office, to the West Java Daily Chair, Quick Response, and fellow volunteers and JQR members, namely Miss Rini and Miss Oci who were willing to accompany the author to collect this research data. Thanks also to the Postgraduate Program of Government Studies, Faculty of Social \& Political Sciences, Universitas Padjadjaran of Bandung who helped writers related to research administration, to my friends who had sacrificed a lot of energy and material time, and gave encouragement and prayers wrapped sincerely to the author.

Finally, to all parties who have contributed to the author in completing this research but cannot be mentioned one by one, the authors would like to thank you. Thus the authors convey this foreword, may Allah always give mercy and wisdom to us all, hopefully this simple work can provide benefits for a spark of scientific progress.

\section{References}

Adam, N. H. (2019). 312 Hari Kerja, Jabar Quick Response Berhasil Mendindak 404 Aduan dan Terima Penghargaan. Bandung: Humas Jabar.

Asshidiqie, J. (2006). Perkembangan dan konsolidasi Lembaga Negara Pasca reformasi. Jakarta: Konstitusi Press.

Ayu, M. R. (2009). Kedudukan Komisi Independen Sebagai State Auxiliary Institutions dan Relevansinya dalam Struktur Ketatanegaraan Indonesia. Jurnal Konstitusi, 1(1).

Basarah, A. (2014). Kajian Teoritis terhadap Auxiliary States Organ dalam Struktur Ketatanegaraan Indonesia. Masalah-Masalah Hukum, 43(1). 
Creswell, J. W. (2012). Metode Penelitian Kualitatif. Yogyakarta: Pustaka Pelajar.

Deliarnoor, N. A. (2018). Studi Konstitusi dan lembaga negara. Bandung: Unpad Press.

Huda, N. (2007). Lembaga Negara Dalam Masa Transisi Demokrasi. Yogyakarta: UII Press.

Iswandi, K., \& Prasetyoningsih, N. (2020). Kedudukan State Auxiliary Organ dalam Sistem Ketatanegaraan di Indonesia. Jurnal Penegakan Hukum Dan Keadilan, 1(2).

Jabar Quick Response. (2019). Standar Operasional Prosedur (SOP). Bandung: Humas Jabar.

Moleong, L. J. (2005). Metodologi Penelitian Kualitatif. Bandung: Remaja Rosdakarya.

Nurtjahjo, H. (2017). Lembaga, Badan, dan Komisi Negara Independen (State Auxiliary Agencies) di Indonesia: Tinjauan Hukum Tata Negara. Jurnal Hukum \& Pembangunan, 35(3), 275. https://doi.org/10.21143/jhp. vol35.no3.1518
Ramdhani, H. (2019). Realitas Elit Politik Lokal dan Persepsi Masyarakat dalam Proses Pemekaran Daerah. JPPUMA Jurnal Ilmu Pemerintahan Dan Sosial Politik Universitas Medan Area, 7(2), 219. https://doi.org/10.31289/jpp uma.v7i2.3014

Satriawan, I., \& Mokhtar, K. A. (2019). The Role of Indonesian Constitutional Court in Resolving Disputes among the State Organs. Hasanuddin Law Review, 5(2), 159. https://doi.org/10.20956/halr ev.v5i2.1669

Sugiyono, S. (2007). Metode penelitian kuantitatif, kualitatif dan $R$ \& D. Bandung: Alfabeta.

Triningsih, A., \& Mardiya, N. Q. (2018). Interpretasi Lembaga Negara dan Sengketa Lembaga Negara dalam Penyelesaian Sengketa Kewenangan Lembaga Negara. Jurnal Konstitusi, $\quad$ 14(4), 778. https://doi.org/10.31078/jk1 444

(C) 2020 by Authors. Submitted for possible open access publication under the terms and conditions of the Creative Commons Attribution (CC-BY-SA) license (https://creativecommons.org/licenses/by-sa/3.0/). 